\title{
Judicial Analysis on Ownership Evidence for Shareholders in a Scripless Share Trading System in Stock Exchange
}

\author{
Suratman* \\ The Lecturer of Faculty of Law, Islamic University of Malang \\ Moh. Bakar Misbakul Munir \\ The Lecturer of Faculty of Law, Islamic University of Malang \\ Ana Rokhmatussa'dyah \\ The Lecturer of Faculty of Law, Islamic University of Malang
}

\begin{abstract}
Transfer of property rights on share in scripless trading system in stock exchange related to ownership evidence for scripless shareholdres is not regulated yet in the procedure law. In fact, it becomes important for the sake of legal certainty. The electronic document is equal to the document made on paper. Therefore, the implementation of Law of the Republic of Indonesia Number 11 of 2008 regarding Electronic Transaction and Information is the answer of the technological development and advancement, especially information technology field, so that it can be used to anticipate the harmful possibilities that may happen. Based on formal-judicial aspect, Civil Procedure Law and Criminal Procedure Law do not accommodate electronic documents yet as the evidence. The regulation on electronic evidence in formal law is extremely needed in order to achieve legal certainty. Ownership evidence for shareholders in scripless share trading system is in form of beneficial ownership on securities, provided by the Custodian to securities account holders in form of written confirmation, regarding the sales or the purchase of securities, providing receipts of securities deposit into securities account, confirming on securities receipts or deliveries, providing monthly securities account reports on debits and credits in the securities account, and providing other documents issued by the Custodian regarding debits and credits in the securities account, including electronic confirmation. The written confirmation for the Custodian to the securities account holders is actually the ownership evidence on share in form of electronic data.
\end{abstract}

Keywords: Ownership Evidence, Scripless Share Trading

DOI: $10.7176 / \mathrm{JLPG} / 91-06$

Publication date: November $30^{\text {th }} 2019$

\section{Introduction}

In Civil Procedure Law, to prove an excuse about the rights and obligations in a dispute in court, the types have been determined limitatively in law. The types of evidence that become the legal basis of evidence are regulated in Article $164 \mathrm{HIR} /$ Article $284 \mathrm{RBg} /$ Article $1866 \mathrm{BW}$ which are:

a. Written evidence;

b. Witness evidence;

c. Allegation evidence;

d. Testimony evidence;

e. Oath evidence.

In Article 16 sub-section (1) in Law Number 4 of 2004 regarding Principal Provisions on Judicial Power, it is mentioned that the judge is not allowed to refuse to investigate and to adjudicate a case proposed to him with the reason that law does not regulate it or the law is unclear. Therefore, the judge is obliged to dig, follow, and understand legal values existing in the community. If the judge meets difficulties in the practice, he should look for solution through doctrine or teachings of scholars and jurisprudence.

In criminal procedure law, what is sought is material truth which means that in seeking for truth, the judge is not bound by any information or evidence submitted by the prosecutor or the defendant only, even the judge is prohibited from accepting the truth of the event based on the defendant's testimony solely because the purpose of the criminal procedure law is not to settle a dispute. Since the criminal procedure law is more related to the rights of the accused, the requirements are more burdening, so that the judge is not bound by what the prosecutor or the defendant has stated solely. In the civil procedural law, what is sought is formal truth, which means that the judge is bound to the events recognized by the defendant or what is not disputed. Here, it is enough to have evidence that is not convincing, but feasible. In the civil procedural law, a positive proof system is adopted, meaning that in a positive burden of proof system, what is sought is the formal truth. ${ }^{1}$

${ }^{1}$ Hari Sasangka, Burden of Proof Law in Civil Case for University Students and Practitioners, CV Mandar Maju, Bandung, 2005, p. 25-26 
In the court session, the parties that have to prove are the disputed parties, while the judge orders the parties to submit evidence to justify the reasons/events stated. In the civil procedure law, to prove an excuse about the rights and obligations in a dispute in court, the types have been determined limitatively in the law.

In the civil procedure law, the designation of written evidence (what is intended is letter) is the primary evidence because the letter ismade precisely to prove a situation, or an event that has occurred or a legal act that must be done by a person eventually. It is different from the designation of evidence in the criminal procedure law. In Article 184 sub-section (1) of the Criminal Procedure Law, the order of evidence is stated below namely:

a. Witness statement;

b. Expert statement;

c. Letter;

d. Clue;

e. The accused statement.

From the order of evidence designation, it can be concluded that the primary evidence in criminal case is witness statement. It is because someone committing crime will attempt to get rid of his footprint. Therefore, in criminal case, the burden of proof will be concerned on witness statement. The other evidences in the procedure mentioned in laws are:

a. Local inspection (Article $153 \mathrm{HIR} /$ Article $180 \mathrm{RBg}$ );

b. Expert statement (Article $154 \mathrm{HIR} /$ Article $181 \mathrm{RBg}$ ).

Meanwhile, there are evidences in the procedural law which are not mentioned in the law, for example, photos, films, video/tape/CD recordings, microfilm, and microfische. It should be in mind to consider about the new evidences that now exist in the law of modern world as a result of technological advancement, to what extent their burden of proof power in modern burden of proof law noawadays. According to Achmad Ali and Wiwie Heryani, the new-coming evidences include:

a. Phone talks;

b. Blood testing;

c. Computer output;

d. Photocopy;

e. Cassette recording;

f. Photography output, and so forth. ${ }^{1}$

On the other hand, according to GW. Paton, the evidences can be:

a. Oral: is the words stated in the court session including witness statement;

b. Documentary: letter.

c. Demonstrative evidence: is the the evidence in form of material and other physical objects, e.g. film, photos, and so forth. ${ }^{2}$

Besides, the procedural law prevailing in Indonesia does not accommodate this. Therefore, according to Satjipto Rahardjo ${ }^{3}$, law enforcers are needed to make breakthrough steps in carrying out the law. It is important to do because many regulations are outdated, contradictory and overlapping. Thus, the presence of wise, visionary and creative legal actors is absolutely necessary to guide the meaning of these regulations.

This article is written regarding the transfer of property rights on share in scripless trading system in stock exchange, regarding ownership evidence for scripless shareholders, considering it is not regulated limitatively yet in the procedural law. It is important for the sake of legal certainty. This article is the research result which attempts to dig and to find ownership evidence for shareholders regarding to the technological development and advancement nowadays

\section{Research Problems}

From the short explanation above, there are several problems that will be discussed which are:

a. How is the position of electronic evidence in the perspective of legislation?

b. What becomes the ownership evidence for shareholders in scripless trading system in stock exchange considering the procedural law does not regulate it and how is the form?

\section{Research Method}

Research method plays a significant role in the arrangement of scientific paper. The research methods used in this research are:

\footnotetext{
${ }^{1}$ Ahmad Ali, and Wiwie Heryani, Principles of Burden of Proof, Kencana Prenada Media Group, Jakarta, 2012, p. 78

${ }^{2}$ Hari Sasangka, op.cit., p. $40-41$

${ }^{3}$ Satjipto Rahardjo, Progressive Law (Exploration of an Idea), The paper was delivered in the Alumni Meeting of Doctrol Program of Law in Diponegoro University, Semarang, dated September $4^{\text {th }}, 2004$.
} 
3.1 Research Type

Research is a scientific work related to the analysis done methodologically, systematically, and consistantly. ${ }^{1}$ This research is a normative law research meaning that the research which is based on the logic of normative law research science developed based on scientific discipline and procedures of normative law, which is the science in which its subject is the law itself. ${ }^{2}$ This research, in some parts, is equipped with empirical research regarding the transfer of property rights on scripless share trading system in the stock exchange related to the development of information technology (IT); however, it is only a support to obtain complete description in the discussion of the problems formulated in this research.

\subsection{Problem Approach}

In the legal research, there are some approaches. In the approach, it is expected to obtain information from some aspects regarding the issues in which the answers are being searched. The approaches used in this research are such as:

3.2.1 Conceptual approach

This conceptual approach utilizes views and doctrines developing in jurisprudence. By learning about views and doctrines in jurisprudence, it is expected to be able to bear legal definitions, legal concepts, and legal principles related to the issue faced. ${ }^{3}$ This approach is qualitative aiming to understand the meaning of substantive problems regarding previling legal values, legal principles, and legal norms.

3.2.2 Statute approach

Normative legal research with the statute approach is conducted by examining all laws and regulations related to the legal issues which are being discussed. This statute approach is used because this research focuses on the study of norms in a legal regulation especially those related to scripless trading system, so that ratio legis ratios and ontological basis can be found of scripless share trading regulations (scripless trading) in the stock exchange. ${ }^{4}$

\subsection{Legal Material Source}

Considering that this research is a normative law research, thus, the primary material studied and used is in form of legal material comprising of primary legal material and secondary legal material.

Primary legal material is the legal material that has binding power. Primary legal material is an authoritative legal material, meaning that it has authority. Primary legal material consists of applicable legislation, such as:

a. 1945 Constitution of the Republic of Indonesia;

b. Civil Code;

c. Law Number 8 of 1995 regarding Capital Market;

d. Law Number 11 of 2008 regarding Electronic Transaction and Information;

e. Government Regulation Number 45 of 1995 regarding Investigation Procedure in Capital Market Field;

f. Government Regulation Number 12 of 2004 regarding the Amendment of Government Regulation Number 45 of 1995 regarding Activity Implementation in Capital Market;

g. Decrees of the Minister of Finance of the Republic of Indonesia, concerning ownership of shares, purchase of shares, listing of securities, trading of securities;

h. Decisions of the Directors of Stock Exchange;

i. Regulation of Capital Market Supervisory Agency and Financial Institution (Bapepam - LK or Financial Services Authority)

Secondary legal material ${ }^{5}$, adalah the legal material that isclosely related to primary legal material and can help to analyze and to understand primary legal materials, such as:

a. Law Draft;

b. Scholars' scientific work; and

c. Research results.

\subsection{Legal Material Collection and Processing}

The collection of legal materials, both primary and secondary legal materials, is done by studying and recording the legal materials needed. Legal material is collected by using documentation study technique. Documentation study is conducted by reviewing several documents and legal regulation that prevail, which are directly or indirectly related to the issue discussed specifically regarding to ownership evidence for shareholders in a scripless trading system in the stock exchange, considering that procedural law does not regulate it and how its

\footnotetext{
${ }^{1}$ Jhonny Ibrahim, Theory and Methodology of Normative Legal Research, Bayu Media, Malang, 2011, p. 294.

${ }^{2}$ Ibid., p. 57

${ }^{3}$ Peter Mahmud Marzuki, Legal Research, Kencana Prenada Media Group, Jakarta, 2008, p. 95

${ }^{4}$ Ibid., p. 94.

${ }^{5}$ Suratman and Philips Dillah, Legal Research Method, Penerbit Alfabeta, Bandung, 2013, p.
} 
form which becoe the research objects, such as: Civil Code, Law Number 8 of 1995 regardingCapital Market; Government Regulation Number 45 of 1995 regarding Investigation Procedures in the Capital Market; Government Regulation Number 12 of 2004 regarding Amendment of Government Regulation Number 45 of 1995 regarding the Activity Implementation of Capital Market; Decrees of the Minister of Finance of the Republic of Indonesia regarding ownership of shares, purchase of shares, listing of securities, trading of securities trading, etc., and Decisions of the Directors of Stock Exchange as well as Regulation of Capital Market Supervisory Agency and Financial Institution (Bapepam - LK) (now Financial Services Authority). Afterwards, the legal material is chosen and distinguished based on the nature of the legal material, so that it can be used to analyze the research problems formulated. The collection of legal material is intended to facilitate its arrangement in discussing the problems stated in the research problem.

In certain parts, it is complemented by empirical research on ownership evidence for shareholders in a scripless stock trading system in the stock exchange related to the development of information technology (IT). It is done as a support in order to obtain a complete description in the problem discussion.

\subsection{Legal Material Analysis}

After all legal materials has been successfully collected and identified, analysis of the legal materials is conducted. In conducting this analysis, the researchers use a prescriptive analysis method, namely conducting analysis by describing or explaining existing regulations related to the issues discussed in the scripless trading system, so that conclusion can be made.

\section{Discussion}

\subsection{The Legal Position of Electronic Evidence in the Perspective of Legislation}

In cyberspace, the law enforcers will experience problems when related to the burden of proof and the law enforcement because they have to prove a problem that is assumed to be virtual, something unseen and pseudo. The evidence is electronic, such as in form of electronic document, in which until now it has not been regulated yet in the procedural law as formal law, but in practice, it is well-known and widely used. The current regulation of electronic evidence is still in the level of material law which contains formal legal provisions (procedural law) as in Law Number 11 of 2008 regarding Electronic Transaction and Information (abbreviated as UU-ITE).

As it is known, the purpose of law is to create justice and to provide legal benefits and legal certainty. The presence of Electronic Transaction and Information (UU-ITE) is expected to be beneficial for the community to anticipate and to overcome various possibilities in the implementation of electronic systems. Electronic evidence, in form of electronic data or documents, has not been regulated yet in procedural law as a formal law (Criminal Procedure Law and HIR). However, because it provides benefitsfor the community, the electronic evidence that is regulated in the Electronic Transaction and Information (UU-ITE) as a material law, may be used as legal evidence for the purpose of burden of proof in court session. However, the regulation of electronic evidence in formal law (procedural law), both civil procedural law and criminal procedure law, is still needed for the achievement of legal certainty.

Based on the provision of Article 1 number 2 of the Electronic Transaction and Information (UU-ITE), what is meant by electronic transaction is a legal act that is conducted and uses computers and/or other electronic media. In the context of conducting such electronic transactions, the parties will always use an electronic document as a basis for them to have legal relations. Regarding to the existence of electronic transactions which use electronic documents, in the Electronic Transaction and Information (UU-ITE), there is a principle that determines that everyone who declares rights, strengthens existing rights, or rejects the rights of others (The same principle is in Article 163 HIR jo Article 1865 of the Civil Code), based on the existence of electronic information and/or electronic documents, must ensure that the electronic information and/or electronic documents available are from electronic systems that meet the requirements based on legislation.

The requirements mentioned in the Electronic Transaction and Information (UU-ITE) are the requirements for electronic transactions and/or electronic documents in which their both subject and system must be certified by: (1) Reliability Certification Agency which will perform administrative functions, which can include: Registration; Physical authentication towards business actors; Making and managing reliability certificates; and Making a list of certificates that have been abandoned, as specified in Article 10 of the Electronic Transaction and Information (UU-ITE); (2) Electronic Certification Service Provider which performs administrative functions which can include: Registration; Physical authentication of the appellant; Making and managing public and private keys; Managing electronic certificates and List of abandoned certificates as specified in Article 13 and Article 14 of the Electronic Transaction and Information (UU-ITE).

In the burden of proof system in Indonesia (the civil burden of proof based on HIR), the judge is bound by valid evidence, which means that the judge may only make decisions based on the evidences determined by the law only. The evidence in the Civil Procedure Law mentioned by lawis regulated in Article 164 HIR, 284 RBg and 1866 in Civil Code, while the evidence in the Criminal Procedure Law is in Article 184 sub-section (1) in 
the Criminal Procedure Law.

Along with the development of information technology and telecommunication, in its development now, electronic evidence is known, for example: electronic information, electronic data/documents, inspection of witnesses using teleconferences, micro films containing recorded company documents in addition to other evidence, such as: cassette radio records, VCD/DVD, photos, faxes, CCTV recordings, and even SMS/MMS.

Photographs (portraits) and sound recordings or images (in its development including CCTV recordings) cannot be used as evidence because they can be engineered, so they cannot prove what actually happens, but in its development today, with technological advancement in in the field of information and telecommunication, the originality of a photograph and sound recordings or images be identified by using certain techniques. The printing out of a faximile machine (known as a fax) is largely used in the long-distance correspondence in a short time, as well as microfilm or microfische which is used to store data; whether it can be considered as written evidence or not.

The Supreme Court of the Republic of Indonesia in its letter to the Minister of Justice dated January 14, 1988 Number 39/TU/88/102/Pid stated that microfilm or microfiche can be used as legal evidence in criminal cases in the court which replace documentary evidence as long as the microfilm records' authenticity are previously guaranteed which can be traced back from the registration and news. Regarding to civil cases, the same opinion is also applied. If the opinion of the Supreme Court is acceptable, it is in accordance with the opinion of GW. Paton, namely the evidence can be: oral which is the words stated in front of the court session such as witness statement; documentary in form of letters; and demonstrative evidence which is the evidence in form of material and other physical objects such as photographs, films, CDs, and so forth. ${ }^{1}$

Based on formally judicially, the law of burden of proof in Indonesia (in this case, procedural law as a formal law), both the HIR/Civil Code and the Criminal Procedure Law have not accommodated electronic documents as evidence yet, while several new laws have governed and recognized electronic evidence as legal evidence including: Law Number 8 of 1997 regarding Company Documents; Law Number 36 of 1999 regarding Telecommunications; Law Number 40 of 1999 regarding Press; Law Number 20 of 2001 regarding Eradication of Corruption; Law Number 19 of 2002 regarding Copyright; Law Number 30 of 2002 regarding the Corruption Eradication Commission; Law Number 24 of 2003 regarding the Constitutional Court; and Law Number 11 of 2008 regarding Electronic Transaction and Information.

However, although the law of the Company Document, the law of Electronic Transaction and Information, and ohter legislations have been there, but it cannot be stated that the Indonesian procedural law (both civil and criminal) has regulated the electronic evidence in civil burden of proof. It is because the arrangement of electronic evidence that has been done is in the field of material law (which also includes procedural law), not a formal legal field in its own right. Considering the nature of the procedural law which is binding for those who use it, including for judges (because according to the procedural law system in Indonesia, the burden of proof is only valid if it is based on evidence that has been regulated in the law/procedural law), then the arrangement of electronic evidence in formal law (procedural law), both civil procedural law and criminal procedure law, is still needed for the achievement of legal certainty.

Actually, there are some actions that lead to the use and the recognition of electronic documents as legal evidence, for example, by the introduction of online trading in the stock exchange and microfilm regulation as well as electronic means as media for storing company documents regulated in Law Number 8 of 1997 regarding Company Documents. The Law on Company Documents can be stated as the beginning of the electronic evidence regulation because it has provided the possibility for company documents that have been given positions as authentic written evidence to be secured through safekeeping in form of microfilm. Moreover, the documents stored in electronic form (paperless) can be used as legal evidence if a dispute eventually happens in the court session. Therefore, it can be stated that the emergence of the Company Document Law is the starting point for the recognition of electronic evidence in form of electronic documents as evidence that can be submitted to the Court.

In addition, in Law Number 24 of 2003 regarding the Constitutional Court (even though it is not within the scope of civil dispute resolution), it also inserts the regulation of the procedural law, stipulated in Article 36 subsection (1) regarding the evidences that can be used in the burden of proof at the hearing of the Constitutional Court, which are:

a. Letter/written form;

b. Witness statement;

c. Expert statement;

d. Parties statements;

e. Clue,

f. Other evidence in form of information stated, delivered, received, or saved electronically with optical tool or

\footnotetext{
${ }^{1}$ Ahmad Ali and Wiwie Heryani, op.cit, p. 74
} 
similar to it.

In Law Number 30 of 1999 regarding Arbitration and Alternative of Dispute Resolution, it has recognized electronic information as a notification document through Article 8 sub-section (1) stating that "in the event of a dispute occurring, the appellant must notify by registered letter, telegram, telex, faximile, e-mail, or expedition book, to the respondent that the terms of arbitration held by the appellant or the respondent are applied".

More specifically about the regulation of electronic evidence, it has also been regulated through the Electronic Transaction and Information Law which specifically regulates electronic evidence. In Article 5 of the Electronic Transaction and Information Law, it is stated expressly that the information and/or electronic documents and/or printouts are the legal evidences and they have valid legal consequences. ${ }^{1}$ More completely, in Article 5 of the Electronic Transaction and Information Law, it is stated that: (1) Electronic Information and/or Electronic Documents and/or printouts are the legal verification tools; (2) Electronic Information and/or Electronic Documents and/or printouts are in accordance with the sub-section(1) are taken from valid evidence in accordance with the applicable Procedure Law in Indonesia; (3) Electronic Information and/or Electronic Documents approved using the Electronic System are in accordance with the provisions stipulated in this law; (4) Provisions regarding Electronic Information and/or Electronic Documents requested in sub-section (1) do not apply to: a). Letters which according to the law must be in written form; (e.g. issuing letters but not limited to securities, and letters which are used in the process of law enforcement in civil procedure, courts and state administration); and b). The letter and its document made by law must be in the form of a notarial deed or a deed made by the public deed official.

From the description aforementioned, it can be stated that generally, the form of electronic evidence is in the form of electronic information and electronic documents, in addition to witness inspection using teleconference.

According to Article 1 sub-section (3) of the Electronic Transaction and Information Law, what is meant by Electronic Information is: "One or a set of electronic data, including but not limited to texts, sounds or pictures, maps, designs, photographs or others, letters, signs, numbers, access codes, symbols or perforations which have meaning or can be understood by people who are able to understand it that has been processed so that it has a meaning."

The limits regarding electronic documents as stipulated in sub-sub-section(14) of the article above are: "Any electronic information created, forwarded, sent, received, or stored in analog, digital, electromagnetic, optical or so forth; which can be seen, displayed and/or heard through a computer or electronic system, including but not limited to texts, sounds or images, maps, designs, photographs or others, letters, signs, numbers, access codes, symbols or perforations that have meaning or can be understood by people who are able to understand it." Actually, the presence of the Electronic Transaction and Information Law is extremely necessary to provide clear and directed legal corridors and to address the importance of the law presence regarding cyberspace, especially those covering the regulation of electronic transactions.

\subsection{Ownership Evidence for Shareholders in Scripless Share Trading Sysstem in the Stock Exchange}

Article 55 sub-section (1) of Law Number 8 of 1995 regarding the Capital Market regulates the system of scripless share trading in the stock exchange by using electronic devices, where the transfer of rights is no longer done physically, cessi or endossemen, but by book-entry settlement. For shareholders, ownership evidence as a result of the scripless trading is extremely essential because it has a relatively high economic value. In a scripless share trading system, evidence of beneficial ownership on securities is provided by the Custodian to securities account holders in form of written confirmation, regarding the sales or the purchase of securities, providing receipts of securities deposit into securities account, confirming on securities receipts or deliveries, providing monthly securities account reports on debits and credits in the securities account, and providing other documents issued by the Custodian regarding debits and credits in the securities account, including electronic confirmation. The written confirmation for the Custodian to the securities account holders is actually the ownership evidence on share in form of electronic data.

If it is necessary for the purpose of verification, the electronic data or the results of the print-outs can be used as legal evidence in the court session. It is in accordance with the provisions of Article 5 sub-section (1) of the Electronic Transaction and Information Law which states that information or electronic documents and/or printouts are legal evidence.

Electronic evidence must meet the requirements both formally and materially, so that the evidence can be declared valid and used in the court session. These provisions and requirements aim to guarantee legal certainty and function as a testing tool in determining the validity of evidence; the absence of the intended testing tool can complicate the emergence of a judge's conviction.

Regarding to the validity and the strength of electronic document verification after the enactment of the

${ }^{1}$ Ibid., hlm 12 
Electronic Transaction and Information Law, there is a new regulation related to electronic document evidence. Based on the provisions of Article 5 sub-section (1) of the Electronic Transaction and Information Law, it is regulated that electronic information and/or electronic documents and/or printouts are valid legal evidence. Furthermore, in Article 5 sub-section (2) of the Electronic Transaction and Information Law, it is regulated that electronic information or electronic documents and/or printouts as referred to in sub-section (1) is the elaboration of legal evidence in accordance with the prevailing procedural law in Indonesia.

By the presence of the Electronic Transaction and Information Law, electronic evidence is legally recognized as evidence that can be submitted in the court session. Recognition of electronic evidence as legal evidence can be used in Courts regulated in the Electronic Transaction and Information Law, it is not enough to meet the interests of judicial practice because it is only an arrangement in the level of material law. Considering that judicial practice is based on procedural law as a binding formal law, the regulation of electronic evidence (as legal evidence to be submitted to the court) in the form of formal law/procedural law is indispensable for achieving legal certainty. Civil Procedure Law and Criminal Procedure Law as formal law, which contain procedures or regulations for litigation in a court which are coercive and binding for judges and litigants, must explicitly regulate and acknowledge electronic evidence as legal evidence in the court.

The Civil Procedure Law Draft has accommodated electronic evidence by formulating open regulations (evidence system) which stipulate that burden of proof can be done with all evidence, unless the law otherwise stipulates.

Although electronic evidence has not been explicitly regulated in the Civil Procedure Law or the Criminal Procedure Law, but based on the principle of justice that the judge must not refuse to investigate and to decide on a case submitted to him even if the legal base is unclear or non-existent, and the principle that the judge is obliged to explore the legal values that grow and develop in society, the Electronic Transaction and Information Law which has set electronic evidence as legal evidence, can be used as a basis for making electronic evidence as legal evidence in the court.

\section{Conclusion}

The conclusions that can be made from the above explanation are as follows:

a. Related to the position of electronic evidence, based on formal judicial aspect, both the Civil Procedure Law and the Criminal Procedure LAw have not accommodated electronic documents as evidence, but several new laws have regulated and recognized electronic evidence as valid evidence, such as the Company Documents Law and Electronic Transaction and Information (UU-ITE) as well as several other laws and regulations. The electronic evidence arrangement is in the material legal field; not a formal legal field in itself. Considering the nature of the procedural law which is binding on those who use it, including judges, the regulation of electronic evidence in formal law, both Civil Procedure Law and Criminal Procedure Law, is still needed for the achievement of legal certainty.

b. Ownership evidence for shareholders in a scripless share trading system is in the form of evidence of beneficial ownership of securities, provided by the Custodian to securities account holders in form of written confirmation, regarding the sales or the purchase of securities, providing receipts of securities deposit into securities account, confirming on securities receipts or deliveries, providing monthly securities account reports on debits and credits in the securities account, and providing other documents issued by the Custodian regarding debits and credits in the securities account, including electronic confirmation. The written confirmation for the Custodian to the securities account holders is actually the ownership evidence on share in form of electronic data.

\section{References}

Ali, A., \& Heryani, W. (2012). Asas-Asas Hukum Pembuktian Perdata. Jakarta: Kencana.

Tanya, B. L. (2007). Teori Hukum: StrategiTertib Manusia Lintas Ruang dan Generasi, Surabaya: CV.

Fakhriah, E. F. (2014). Kedudukan Bukti Elektronik Sebagai Alat Bukti di Pengadilan Setelah Berlakunya Undang Undang No 11 Tahun 2008 Tentang Informasi dan Transaksi Elektronik.

Wahyudi, J. (2012). Dokumen elektronik sebagai alat bukti pada pembuktian di pengadilan. Perspektif, 17(2), $118-126$

Sasangka, H. (2005). Hukum Pembuktian dalam perkara perdata untuk Mahasiswa dan praktisi. Mandar Maju. Ibrahim, J. (2006). Teori dan metodologi penelitian hukum normatif. Malang: Bayumedia Publishing, 57.

Sitompul, J. (2010). Pengaturan Alat Bukti Elektronik: Mencari Betuk dan Jati Diri. Jurnal Hukum Bisnis, 29(2).

Marzuki, P. M. (2008). Penelitian Hukum. Jakarta: Kencana Prenada Media Group.

Rahardjo, S. (2004). Hukum Progresif (Penjelajahan Suatu Gagasan). Makalah disampaikan pada acara jumpa Alumni Program Doktor Ilmu Hukum Undip Semarang.

Suratman, \& Dillah, P. (2013). Metode Penelitian Hukum. Bandung: Alfabeta. 